\title{
The socio-economics dynamics of Dam on Rural Communities: A case study of Oyan Dam, Nigeria
}

\author{
Amidu Ayeni and Lawrence Ojifo \\ Department of Geography, University of Lagos, Nigeria \\ Correspondence: Amidu Ayeni (aayeni@unilag.edu.ng)
}

Received: 9 December 2017 - Revised: 23 February 2018 - Accepted: 27 February 2018 - Published: 5 June 2018

\begin{abstract}
Dams construction and operations have many benefits, nevertheless, they have also led to lots of negative social, health and human impacts. It is based on this that this study assesses the potential and socioeconomics dynamics of Oyan dam between 1980 and 2016. The data used for this study include water level and discharge records of the dam between 2007 and 2016, Landsat imageries of 1984 and 2016 and socio-economic datasets for the period. Analysis of the dam potentials (water supply, agriculture and hydropower) and socioeconomic impacts of the dam were carried out using basic statistical tools, land use change anaysis and field survey using questionnaire, structured interview with major stakeholders and personal observation. The results revealed that the water level and storage of the Oyan dam had a relative reduction of about $2 \%$ as well as non-stationarity pattern of water abstraction and production for the period. The landuse classes show all classes decreased in extent except the cultivated landuse that acrued an increased of $19.9 \%$ between 1984 and 2016. Furthermore, commercial water supply varied significantly between 2010 and 2016 while irrigation scheme is grossly under-utilized from the inception in 1983 to 2016. Finally, the result of socio-economic impacts revealed that majority of the selected communities' members are actually not benefiting from the dam and their livelihoods are not from the dam.
\end{abstract}

\section{Introduction}

The occurrence and impact of the 1972-1975 Sahelian drought aggravated the food security in the country which prompted various arms of government to embark on a rigorous policy to increase food production (Taviano and Marcelo, 2010). To accomplish the policy, river basins impoundment was seen as inevitable to provide sufficient water for yearround irrigation which led to the construction of over 246 dams (Imevbore et al, 1986). Of the 323 dams in Nigeria in 2002, 106 of them are large dams (dams with walls higher than $15 \mathrm{~m}$ or $10-15 \mathrm{~m}$ high with a crest length of over $500 \mathrm{~m}$ or having a reservoir capacity of 1 million $\mathrm{m}^{3}$ ), 27 are medium sized dams (walls are 8-10 m high) and 192 are small dams (walls less than $8 \mathrm{~m}$ ) (Ofoezie, 2002; Ogbeide and Uyigue, 2004).

The construction and operation of these dams have yielded many benefits, nevertheless, they have also have led to lots of negative social, health and human impacts (Webbe, 1981; Williams and Wolman, 1984; McCartney and King, 2011).
The environmental changes and social disruption resulting from dams and associated infrastructure (e.g. irrigation schemes) have had adverse effect on health of the local population and downstream communities (Williams and Wolman, 1984; Collier et al., 1996; Richter et al., 2010; Sivongxay et al., 2017). Therefore, access to drinking water, health services and ability to cope with new social and physical environment determine socio-health conditions of the displaced population and/or communities (WHO, 1985; World Commission on Dams, 2000; Richter and Thomas, 2010). It is based on the aforementioned that this study tends to provide answers to these questions (i) What are the designed functions for the establishment of the dam? (ii) what is the present serving condition and/or capacity of the dam functionalities? (iii) What are the socio-economic impacts of the Oyan dam? (iv) what is the spatio-temporal dynamics of the Oyan Basin over the last 31 years? 


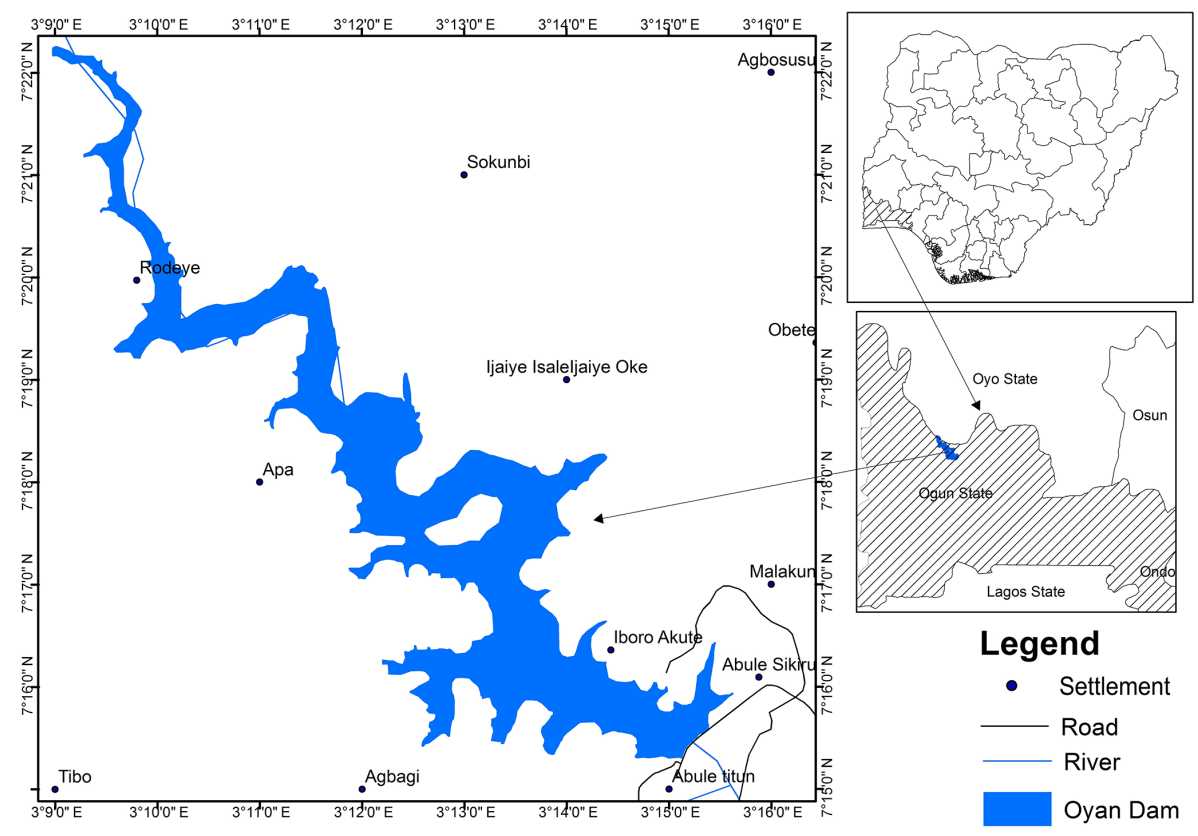

Figure 1. Oyan Dam (Insert - top right: Nigeria; Insert - bottom right: Ogun State).

\section{Study Area}

Oyan dam is located between latitude $7^{\circ} 15^{\prime}$ and $7^{\circ} 25^{\prime} \mathrm{N}$, and longitude $3^{\circ} 08^{\prime}$ and $3^{\circ} 16^{\prime} \mathrm{E}$ near Abeokuta, the capital city of Ogun State, Nigeria (Fig. 1). The dam which is owned and operated by the Ogun-Osun River Basin Development Authority (OORBDA) was commissioned in 1984. Lying adjacent to the dam are three resettlement communities named Abule Sikiru, Abule Titun, and Ibaro. The dam is about $30 \mathrm{~m}$ high with a reservoir (gross storage) capacity of 270 million $\mathrm{m}^{3}$ and a dead storage capacity of 16 million $\mathrm{m}^{3}$ and 9-megawatt power generation capacity. It has a surface area of $40 \mathrm{~km}^{2}$ and catchment area is approx. $9000 \mathrm{~km}^{2}$ with embankment crest length of $1044 \mathrm{~m}$. The dam design free board at 10000 years flood is $2.10 \mathrm{~m}$ high with four spillway gates (each with $15 \mathrm{~m}$ wide and $7 \mathrm{~m}$ high), and three outlet valves (each with $1.8 \mathrm{~m}$ in diameter). It supplies water for irrigation and for domestic uses to the cities of Abeokuta and Lagos.

\section{Methodology}

The data used for this research work include hydrological, remotely sensed, and socio-economic datasets. Each of these datasets were used to achieve the objectives of the study. Hydrological dataset consists of the daily hydrological records for the last 10 years (i.e. 2007-2016). This data includes river water level, water discharge, and supply. These data were sourced from the Ogun-Oshun River Basin Development Authority (OORBDA). The collected daily hydrologi- cal datasets were analysed as a function of the monthly data using simple arithmetic mean equation.

The second dataset obtained through field survey using questionnaire and interview was socio-economic data. This data addresses community livelihood profiles, health status of the population, and social impact of the dam on the communities. Socio-economic impact assessment of the dam was carried out in three selected communities around the Oyan dam vis-à-vis Abule Sikiru, Abule Titun, and Ibaro. Structured questionnaire was used to extract information about the socio-economic impact of the dam. The sample size of the communities was based on OORBDC estimated population size of the communities, therefore, about 50,60 , and 50 questionnaires were randomly distributed in Abule Sikiru, Abule Titun, and Ibaro, respectively. The questions examined includes household characteristics, community livelihood profile, socio-economic benefits, and resource potential of the dam. The socio-economic datasets were analysed using basic descriptive statistics method of data analysis.

The last dataset for spatio-temporal dynamics assessment of the dam Basin was based on Landsat imageries of Thematic Mapper (TM) and Enhanced Thematic Mapper (ETM) for 1984 and 2016 respectively. The two periods dataset were obtained from Glovis portal. Six (6) landuse/landcover classes were extracted from each of the imageries using the standard procedures for LULC classification anaysis (de Vries et al., 2007; Chander et al., 2009; Ayeni et al., 2016). In view of this, a certain number of training dataset was randomly sampled from the spectral signature of each of the classes to define their respective landuse/landcover type. 


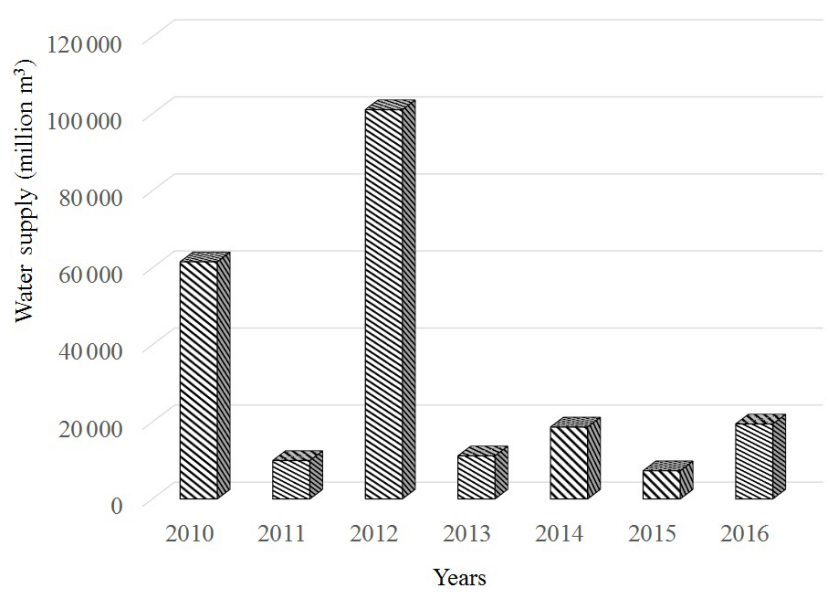

Figure 2. Water Supply of Oyan dam between 2010 and 2016.

Subsequently, the results of the datasets collected were presented in maps, tables and charts.

\section{Results and discussions}

\subsection{The primary functions for the establishment of the dam}

Oyan dam was primarily designed to: (i) generate about 9 megawatts hydro-electric power to support the existing national grid; (ii) supply raw water to Lagos and Abeokuta which are the immediate downstream urban cities, and, (iii) finally to support Lower Ogun basin 3000 ha Irrigation Project. The dam is used for breeding fish. Oyan dam was also designed to function as flood control flood through safe release of water in the downstream. Over the years, cases of flooding in the downstream had been attributed to excess water release from the Oyan dam. In addition, other operational problems have also led to conflicts over the adequacy of water released for downstream uses, irrigation, fisheries and raw water supply for water treatment in Abeokuta city and Lagos State.

Oyan dam capacity of generating over $9 \mathrm{mw}$ of hydroelectric power has been locked since the commissioning in 1984. This implies that the dam currently generates zero megawatt of electricity making it a $100 \%$ decrease in the power generation function. As stated earlier, Oyan dam was designed to supply raw water to the immediate downstream urban cities - Lagos and Abeokuta, and to support the 3000 ha Lower Ogun Irrigation Project. Three turbines of 3 megawatts each were installed in 1983 but they have not been in operation since the inception.

According to OORBDO (2017), the dam has a potential irrigation capacity of 32000 ha of land around the dam and the lower basin irrigation project at Mokoloki. However, the dam presently supports only 8000 and 3000 ha around the dam and at the both upstream/downstream lower irrigation

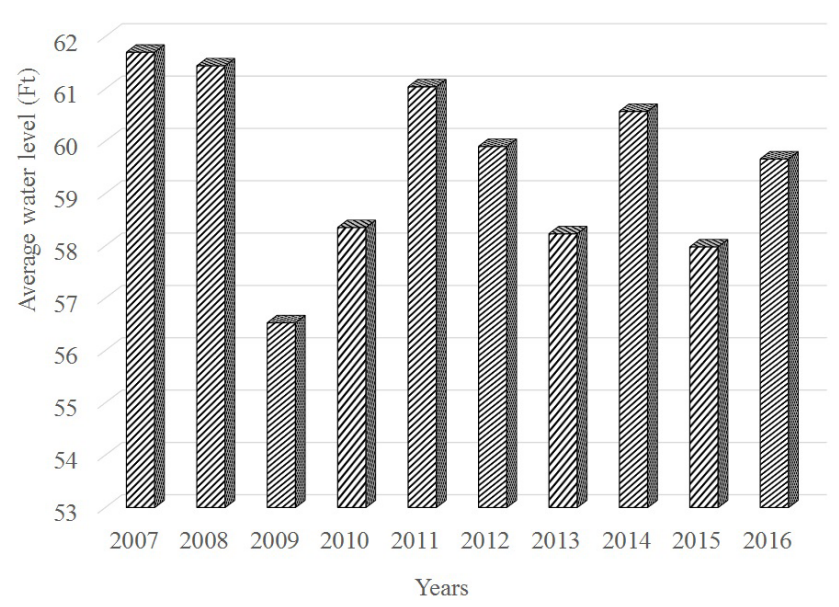

Figure 3. Average Yearly Water Level of Oyan dam Source: OORBDA, 2017.

agricultural project respectively. The water supply pattern of Oyan dam revealed that water was only supply on demand from Ogun and Lagos Water Corporation. The study further revealed that water is supply mostly during the dry season. Thus, certain months received a high demand than the others. Figure 2 shows that 2012 has a highest water supply of about 101041.2 million $\mathrm{m}^{3}$ in the history of the dam. Information revealed that the dam has a capacity to supply more than this volume since there were no set limit for supply from inceptions. Furthermore, based on this data, it can be inferred that Oyan dam has a larger carrying capacity to supply more water than what is currently supplying.

Figure 3 shows the annual water level storage of Oyan dam between 2007 and 2016. The annual average water level storage ranging between $17.23 \mathrm{~m}$ (lowest) and $18.80 \mathrm{~m}$ (highest) in 2009 and 2007 respectively. The figure shows that there is significant high amount of water production in 2007 which account for $10.36 \%$. This explains the percentage of the water abstraction in each of the years, and a level of consistency in water level and storage capacity of dam over a 10 years period.

The monthly water discharge of Oyan dam releases a significant amount of water for domestic and industrial uses. Though, there was data paucity in all years due to certain factors except 2007 which its records show that water was released throughout the year with some months exhibit exceptional discharge rate than the others. It shows that from May to November, the amount of water that was discharged rose significantly (Fig. 4). The figure revealed that January to April record low amount of water discharge ranging from 112 to 192 million $\mathrm{m}^{3}$ while May discharge increased significantly to about 1720 million $\mathrm{m}^{3}$. 


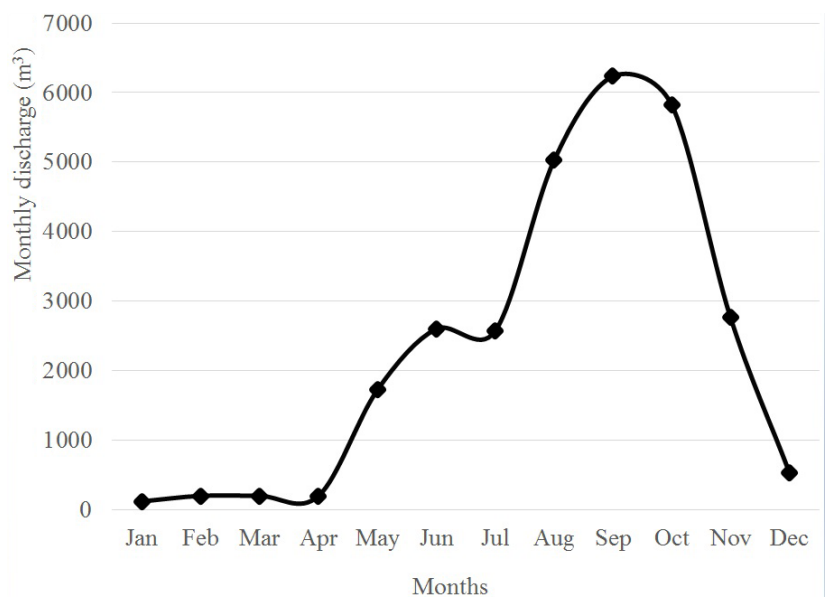

Figure 4. Monthly Water Discharge of Oyan Dam in 2007.

Table 1. Oyan Dam Landuse Dynamics between 1984 and 2016.

\begin{tabular}{lrr|rr}
\hline & \multicolumn{2}{c|}{1984} & \multicolumn{2}{c}{2016} \\
\cline { 2 - 5 } & Area (ha) & $\%$ & Area (ha) & $\%$ \\
\hline Built-up & 121.3 & 0.1 & 81.7 & 0.08 \\
Cultivated & 70860.4 & 72.4 & 90320.4 & 92.3 \\
Floodplain & 14847.6 & 15.2 & 2191.1 & 2.2 \\
Forest & 6624.7 & 6.8 & 2613.7 & 2.7 \\
Rock outcrop & 2861.8 & 2.9 & 737.5 & 0.8 \\
Waterbody & 2524.9 & 2.6 & 1896.3 & 1.9 \\
\hline Total & 97840.7 & 100 & 97840.7 & 100 \\
\hline
\end{tabular}

\subsection{Spatio-Temporal Dynamics of the Oyan Downstream Basin}

Table 1 and Fig. 5 show the six major landuse/landcover classes identified around the Oyan dam for the two scenarios (1984 and 2016).

The classes of landuse/landcover identified include builtup, forest, water body, cultivated land, floodplain and rock outcrop/bare surface. The results show that built-up decreased from 121.3 ha $(0.1 \%)$ in 1984 to about 81.7 ha $(0.08 \%)$ in 2016 (Table 1 and Fig. 5). The changes signify the effect of dam development on small communities which were either relocated or lost to the development. On the other hand, forest decreased from 6624.7 ha $(6.8 \%)$ in 1984 to 2613.7 ha $(2.7 \%)$ in 2016.

However, water body relatively shows a stable slight change. It decreases from with about 2524.9 ha $(2.6 \%)$ in 1984 to about 1896.3 ha (1.9\%) in 2016. Thus, the dynamic nature of this landuse/landcover observed in this basin can be associated with the variation in the water abstraction and production of the dam where the most dominant landuse (Cultivated) demand more water.
Table 2. Purpose of the Water in the Dam.

\begin{tabular}{lrr}
\hline & Frequency & Percent \\
\hline Domestic purpose & 98 & 62.4 \\
Industrial purpose & 13 & 8.3 \\
Commercial purpose & 36 & 22.9 \\
Cultural purpose & 5 & 3.2 \\
\hline Total & 153 & 97.5 \\
& 157 & 100 \\
\hline
\end{tabular}

Table 3. Effect of Dam on Livelihood/Standard of Living of the respondent.

\begin{tabular}{lrr}
\hline & Frequency & Percent \\
\hline Below average & 14 & 8.9 \\
Average & 19 & 12.1 \\
A little above average & 109 & 69.4 \\
very high & 9 & 5.7 \\
\hline Total & 151 & 96.2 \\
& 157 & 100 \\
\hline
\end{tabular}

\subsection{Socio-Economic Impacts of the Dam}

The socio-economic impacts of the dam on the neighboring communities was evaluated on the basis of the community livelihood profiles, health status of the population, and social impact of the dam on the communities.

Table 2 shows the socio-economic benefits of the dam as argued by the respondents. The result shows that more than $86 \%$ of the respondents were fully aware of the dam in their neighborhood. This signifies that the communities' member understands the potentials and socio-economic benefits they can derive directly or indirectly from the dam. It also indicates that more than $62.4,8.3$, and $22.9 \%$ of the respondents use this dam for domestic, industrial and commercial purpose purposes respectively (Table 2).

The results on sources of livelihood derivable from Oyan dam show that about $70.1 \%$ of the respondents are not deriving their livelihood from the dam while only $1.3 \%$ of the respondents claimed they are deriving their livelihood from the dam. Table 3 reveals the effect of the dam on livelihood and/or standard of living of the respondents. It was observed that about $18.9 \%$ of the respondents are living "below average", $12.1 \%$ are on the "average", $63.3 \%$ are above average' while a fraction of about $5.7 \%$ of the respondents had "high" standard of living.

This study reveals that the health status of majority of the population is good as argued by $51.6 \%$ respondents and the presence of dam has nothing to do with their state of health. Displacement and environmental degradation have been identified as the challenges experienced from time to time. Thus, communities expect more from this dam in terms 

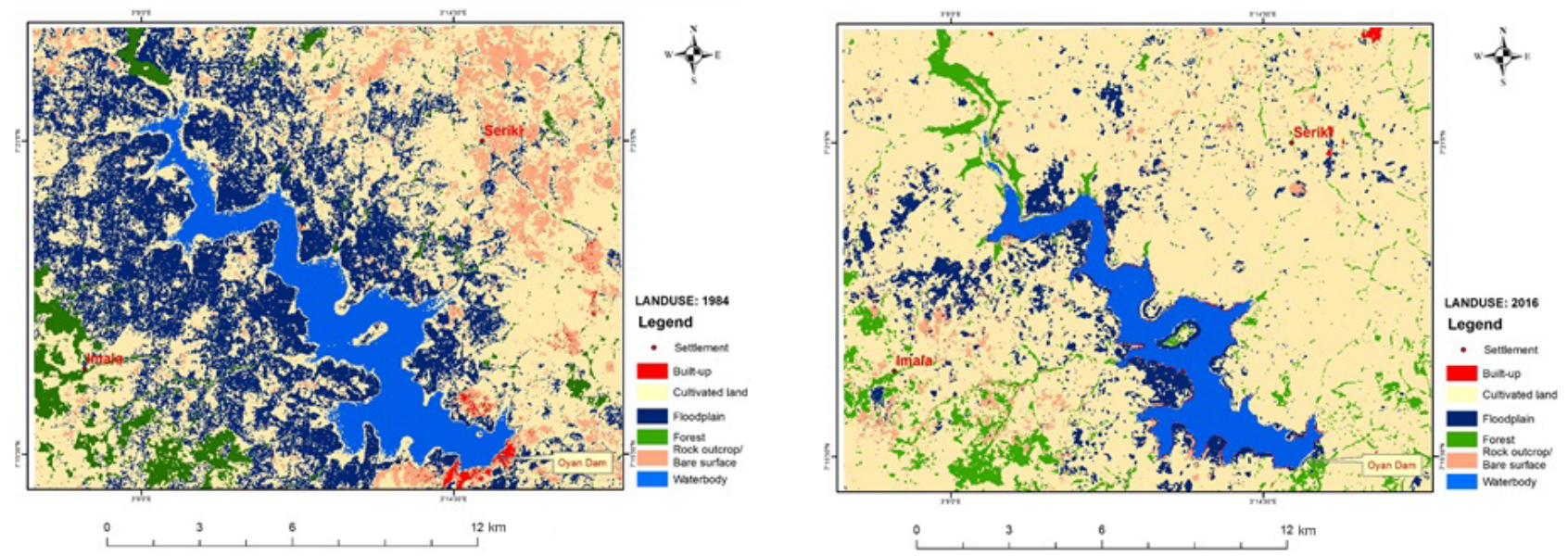

Figure 5. Landuse Pattern of Oyan Dam in 1984 and 2016.

of employment of the local communities, compensation as well as relocation of the displaced communities, and capacity building as pointed out by $36.3,54.8$, and $3.8 \%$ respondents respectively.

These results revealed that the spatio-temporal changes (reduction in water body and forest) around Oyan dam as well as degraded and poor maintenance of dam and associated infrastructure have affected the dam in varying degrees vis-à-vis reduction in dam level and storage capacity, inability to meet the designed water supply capacity, and inability to generates hydro-electric power amongst others. These have had considerable adverse effects on designed functions of the dam and the basin ecosystem, and therefore, resulted to continuous reduction in the serving condition and capacity of the dam especially on irrigation scheme, livelihoods and other socio-economic potentials.

\section{Conclusions}

This study identified two major resource potentials of Oyan dam as at the 2016 vis-à-vis commercial water supply and irrigation scheme. It was observed that the commercial water supply varied with season. Most of the water are supply during the dry season with 2012 accounts for higher percentage of water supply. Irrigation scheme at Oyan upper section (8000 ha) and Makoloki farm settlement (9000 ha) were observed to be under-utilization of water resource potential of the dam while the 9-megawatt hydropower potential is yet to be tapped.

The continuous release of water from Oyan Dam in the recent time has increased the occurrences of downstream flooding at the lower part of the Ogun basin. For instance, there have been persistence flooding ravaging the city of Lagos over the year with significant effects on socio-economic activities. This also resulted to a situation where the irrigation project of the dam has either been under-utilized or none in existence. Series of conflicts have also triggered from other operational activities around the dam. These conflicts emanated from the inadequacy of water released for irrigation, fisheries and raw water supply for domestic water uses in part of Ogun and Lagos States. It is on this premise that the study examines the prime purpose of dam construction, evaluate its carrying capacity in terms of its depth, surface area extent, volume of water generates and agricultural potential, spatiotemporal analysis of the dam was examined between 1980 and 2015 and lastly, socio-economic impacts of the dam development were carried out among its neighboring communities.

The socio-economic impacts of the dam revealed that few people are actually benefiting or deriving their livelihoods from the dam. Thus, communities expect more from this dam in terms of employment of the local communities, compensation and relocation of the displaced communities.

Data availability. Data are available at Ogun-Oshun River Basin Development Authority (OORBDA) head office, Abeokuta, Ogun State, Nigeria.

Competing interests. The authors declare that they have no conflict of interest.

Special issue statement. This article is part of the special issue "Innovative water resources management - understanding and balancing interactions between humankind and nature". It is a result of the 8th International Water Resources Management Conference of ICWRS, Beijing, China, 13-15 June 2018.

Acknowledgements. The Authors are grateful to the Ogun-Osun River Basin Development Authority (OORBDA) for providing 
historical Hydrological dataset.

Edited by: Wenchao Sun

Reviewed by: two anonymous referees

\section{References}

Ayeni, A. O., Cho, M. A., Mathieu, R., and Adegoke, J. O.: The local experts' perception of environmental change and its impacts on surface water in Southwestern Nigeria, Environ. Develop., 17, 33-47, 2016.

Chander, G., Markham, B., and Helder, D.: Summary of current radiometric calibration coefficients for Landsat MSS, TM, ETM+, and EO-1 ALI sensors, Remote Sens. Environ., 113, 893-903, 2009.

Collier, M., Webb, R. H., and Schmidt, R. H.: Dams and rivers: primer on the downstream effects of dams, U.S. Geological Survey Circular 1126, Denver, Colorado, USA, 1996.

de Vries, C., Danaher, T., Denham, R., Scarth, P., and Phinn, S.: An operational invariant target sites, Remote Sens. Environ., 107, 414-429, 2007.

Imevbore, A. M. A., Ofoezie I. E., and Obot E. A.: Report on the study on snail and cyclopoid borne disease: problems of small scale water resources development Nigeria, submitted to the World Health Organization by the Institute of Ecology, O.A.U., Ile-Ife, Nigeria, 1986.

McCartney, M. and King, J.: Use of decision support systems to improve dam planning and dam operation in Africa, Colombo, Sri Lanka: CGIAR Challenge Program for Water and Food (CPWF), 74 pp. (CPWF Research for Development Series 02), 2011.
Ofoezie, I. E.: Human health and sustainable water resources development in Nigeria: schistosomiasis in artificial lakes, Natural Resources Forum, 26, 150-160, https://doi.org/10.1111/14778947.00015, 2002.

Ogbeide, H. E. and Uyigue, E.: Access to safe drinking water and schistosomiasis, in: Nigeria: survey on Ipogun Community, Ondo State of Nigeria, submitted to the Society for Water and Public Health Protection (SWAPHEP), 2004.

OORBDA: Ogun-Osun River Basin Development Authority (OORBDA), 2017.

Richter, B. D., Postel, S., Revenga, C., Scudder, T., Lehner, B., Churchill, A., and Chow, M.: Lost in development's shadow: The downstream human consequences of dams, Water Alternatives, 3, 14-42, 2010.

Richter, B. D. and Thomas, G. A.: Restoring environmental flows by modifying dam operations, Ecol. Soc., 12, 12, 2007.

Sivongxay, A., Greiner, R., and Garnett, S. T.: Livelihood impacts of hydropower projects on downstream communities in central Laos and mitigation measures, Water Resources and Rural Development, 9, 46-55, 2017.

Taviano, C. and Marcelo, G.: The day after tomorrow: a handbook on the future of economic policy in the developing world, The International Bank for Reconstruction and Development/The World Bank, 2010.

Webbe, G.: Schistosomiasis: Some Advances, British Medical Journal (Clinical Research Edition), 283, 1104-1106, 1981.

WHO: Human Health and Dams, WCD Working Paper, 1999.

Williams, G. P. and Wolman, M. G.: Downstream effects of dams on alluvial rivers. U.S. Geological Survey Professional Paper 1286, Denver, Colorado, USA, 1984.

World Commission on Dams: Dams and development: a new framework for decision-making, Earthscan, London, UK, 2000. 